https://doi.org/10.48009/2_iis_2010_145-151

\title{
ACADEMIC CALENDAR CHANGE INDUCED CURRICULUM CHANGE
}

Thom Luce, Ohio University, luce@ ohio.edu

Vic Matta, Ohio University, matta@ohio.edu

\begin{abstract}
In 2008 the Ohio Board of Regents issued a strategic plan for higher education in Ohio. One direct outcome of the plan is the move to a common academic calendar for all state universities and community colleges. This specifically means that the four state universities still using the quarter system will be converting to semesters for the fall, 2012 semester. This calendar change provided a rare opportunity for our MIS program to revise and update our curriculum. While pressures from alumni, advisory boards, industry and the academic community were already suggesting that our curriculum was getting outdated, the mandate to transition from quarters to semesters triggered the change process. This paper describes the current quarter based curriculum, the process used to develop the new curriculum and the new curriculum model for our MIS program.
\end{abstract}

Keywords: IS Curriculum, IS Education, Academic Calendar, Curriculum Change

\section{INTRODUCTION}

In 2007 Ohio Governor Ted Strickland created the University System of Ohio [1] bringing together Ohio's public universities and their branch campuses, community colleges and other workforce and training centers [2]. In 2008 Ohio Board of Regents Chancellor Eric D. Fingerhut delivered a Strategic Plan for Higher Education to the Governor [3]. In 2008 only four of Ohio's public universities were following the quarter system while the rest were under semesters. The Strategic Plan argued that "Having a common academic calendar would allow students greater ease in transferring to institutions that match their academic pursuits and personal circumstances. Their ability to undertake internships and co-ops would be bolstered, and it would provide the chance for all students to take courses that are academically comparable in the depth of instruction provided by semester coursework." [3]. The report went on to say that "Given the significant benefits of a common academic calendar, the universities currently operating on a quarter system should give strong consideration to making the transition to a semester academic calendar." [3]. The MIS department at our university, seeing the writing on the wall, immediately started planning for the switch to semesters, now officially scheduled for the fall of 2012.

It was clear that switching curriculum from a quarter to a semester system would require significant change in the curriculum and course content. The change would be significant because courses would now need to be delivered in shorter class periods, over a longer duration. A comparison of aggregate hours revealed that the MIS curriculum would need to shrink by one or more courses. In addition to the shrinkage there were other issues such as number of MIS courses in the core business curriculum versus those that would be for MIS majors only. The extent of reorganization was sufficient to cause a comprehensive change in a department that was already student and pedagogy focused.

\section{DISCUSSION}

Organizations such as the Association for Computer Machinery (ACM), the Association for Information Systems (AIS) and the Data Processing Management Association (DMPA) (renamed the Association of Information Technology Professionals, AITP) and others have worked to standardize undergraduate Information System's curricula since the early 1970's. A summary of these efforts is found in the forward to the latest joint effort by the ACM and AIS [13]. 


\section{Previous Efforts in Curriculum Revision}

The explosion of the Web and web-enabled commerce, the dot.com bust, the growth of outsourcing and other factors have placed challenges on traditional IS curriculum models. As pointed out by Benamati, Osdemir and Smith [5] in the past employers expected new employees to spend time programming as they learned about the business while in the current environment "... new hires are expected to perform at a higher level of complexity, quickly understanding the business domain and driving projects to completion." Studies reported by Benamati, Osdemir and Smith [5] found senior IS managers looking for project management, systems analysis and design and business domain knowledge as entry-level skills along with leadership skills, team work collaboration and communication skills. Several other studies pointed in the same direction.

As early as 2003 VanLengen [14] observed that the economic environment of the day put pressure on IS curricula that focused on entry-level development skills, especially since many of the programming positions were falling to offshore outsourcing.

A study by Kesner [9] concludes "It may be argued that by refocusing MIS educational program delivery on the applied competencies of project scoping and management, team collaboration, self-directed business research and analysis, business data modeling, and analysis, and the like, educators would better prepare their students for what will be required of them when they transition from the classroom to co-op/internship assignments and eventually to fulltime employment." This finding is reinforced by another study [12] that found soft skills; problemsolving, critical thinking and team skills, to be the most important skills for new IT professionals and another where McGann [11] concludes that IS education has evolved from an emphasis on general technical skills to organization skills and finally to a more integrated model that emphasizes technical, organizational and strategic skills.

A 2008 AMCIS panel on IT Workforce Trends [6] concluded that non-technical skills such as project leadership, project planning, risk management, functional area process and industry knowledge, business process reengineering, communications, and others were critical in-house skills and skills employers sought in new hires. The panel also concluded that some technical skills such as systems analysis and design and IT architecture were also critical in-house skills, while skills like programming, systems testing, database design, database management, and help desk were primarily entry-level skills that could be outsourced.

It wasn't surprising that the findings of these studies correspond closely to feedback from our MIS Advisory Board (MIS-AB) over the past several years. As far back as 2002 the MIS-AB emphasized a need for systems analysis and design skills, knowledge of Information Systems (IS) management and the strategic value of IS and project management along with more traditional entry-level skills. More recently the MIS-AB feedback concluded less need for basic development skills with more emphasis on the "buy" side of build-buy decisions along with more emphasis on enterprise systems, data and knowledge management, and communication systems.

\section{Current Curriculum and Limiting factors}

Our department is part of an AACSB accredited College of Business. Like most accredited business programs our students spend much of their time in core business courses and courses outside the college. According to a recent IS curriculum review [13] the average IS program has approximately eight semester length core and elective IS courses. Our current curriculum [10] includes the eight quarter length courses depicted in Figure 1.

Figure 1 shows a curriculum containing some of the problems outlined above. We currently have two development/programming class (MIS220 and MIS400), systems analysis and design (MIS320), database (MIS380), a networking class (MIS325), a capstone client based project class (MIS420), a capstone IS concepts/big picture class (MIS485) and an ever changing elective class (MIS491). In addition to having too much emphasis on development (build, not buy) we have a networking class that does not easily integrate with the rest of the curriculum and does not fit with the needs expressed by most of our employers. The pairing of the courses as shown in the figure is suggestive of courses that 
work well when taken together. In this form, it takes four quarters to complete the major. Note, the vertical bar between the 300 and 400 level classes is simply an extension of convention used in UML diagramming to denote multiple pre-requisites.

One additional problem with the current curriculum that isn't shown in the diagram relates to the transition from the first MIS course in the business core to the MIS major. In response to a declining number of majors during the last decade; decreases caused by student and parent fears over the perceived technical nature of MIS and the loss of IS jobs to outsourcing, we systematically redesigned the business core Introduction to MIS course to emphasize the importance of information management, design and the role of IS in business [7, 8]. Unfortunately, after exciting students about the possibilities of MIS as a major and a career choice and dismissing the myth about the major being about "computers" and "programming", we plunged them into a fairly traditional technical programming class. This curriculum evolved over the last twenty years in response to industry trends, feedback from our Advisory Board and alums, recruiters of our graduates and, to a lesser degree, national curriculum efforts. Our curriculum development has been constrained by the number of courses allowed in a major and the number of elective courses we can offer while maintaining average class sizes between 30 and 40 students.

\section{The New Curriculum Development Process}

Once it was clear that the university would switch from quarters to semesters and that all departments would need to modify their curriculum we decided to take advantage of the opportunity to approach the change as a business process reengineering opportunity. The only assumption we left on the table was that the major could be, at most, seven courses long (a university requirement that all curriculum changes had to be schedule neutral for current students).

As depicted in Figure 2, department members spent several weeks researching literature, looking at other MIS programs and considering feedback from alumni, MIS-AB members and recruiters. We held a series of weekly meetings where ideas about the shape and direction of the curriculum and individual courses were discussed. At the end of each meeting the department chair created and posted a "Points of Agreement" list for everyone to consider. The next meeting would then begin with a discussion of the points of agreement before moving on to new material.

After several weeks of discussion a straw man model was created in an attempt to bring the ideas and points of agreement from previous discussions together. Over the next several meetings the straw man went through several modifications but remained remarkably intact until the final version, shown in Figure 3, was created.

Having agreed on the overall curriculum model we assigned course champions to each course and asked the champions to create lists of high-level outcomes for each course. The outcomes were discussed and revised in another series of meetings. Once we agreed on the high-level outcomes the course champions were asked to develop a list of objectives of each course, which was subsequently discussed and revised. Finally, each course champion, starting with the capstone courses and working backward, was asked to enumerate all assumptions they had about the knowledge and skills students would bring to their class. We then checked to see if the prerequisite classes would provide students with an opportunity to acquire the necessary knowledge and skills. In cases where the prerequisite knowledge was not available we added appropriate material to one or more courses.

\section{Summary of Changes in the Curriculum}

One of the first issues addressed was that of moving the programming course away from the gateway to the major and deeper into the MIS curriculum. The quarter-based curriculum has two courses that include technical development: Application Development (MIS220) and System Integration (MIS400). A review of the IS 2010 Curriculum guidelines[13], showed that the new IS model does not include application/systems development in its seven course core, but only as one of its seven elective core courses. Further, the occurrence of this area as a track has been decreasing at several conferences, and has completely disappeared from 
leading conferences such as the most recent International Conference on Information Systems (ICIS) in 2009[4]. This curriculum redesign opportunity allowed consolidation of our two development oriented courses into one, System Development (MIS3200), as shown in Figure 3.

The new curriculum starts students in the MIS major with Systems Analysis and Design (MIS2200) and Knowledge Management (MIS2800). Both areas are much closer to what students hear about and get excited about in business core MIS class. Additionally, having MIS2200 and MIS2800 as the first two classes in the major provides a good representation of the career path many will follow upon graduation from our program.

Other important changes include the expansion of MIS380 from a database class into MIS2800, a knowledge management class with significant emphasis on business intelligence. The numbering change also puts both MIS2200 and MIS2800 at the sophomore level and should encourage students to try MIS as a major at an earlier stage of their academic career. We also created Enterprise Systems Implementation (MIS3800) to cover a major hole in our current curriculum. The coupling of this course with Systems Development (MIS3200) mirrors the classic "Build versus Buy" paradigm companies often face.

A second less obvious beneficial impact was the flattening of the curriculum as is apparent from comparing the current and new curriculum models in figures 1 and 3. Notice that the current model uses four layers of courses, and therefore requires a minimum of four quarters to complete. The new model uses three layers and could be completed in three semesters. This change is also supported by the IS 2010 guidelines [13]. More importantly it supports our strategy of aggressively marketing MIS as the ideal double major with any other functional area in business. Under the new curriculum an accounting, finance or marketing major could decide to add MIS as a second major as late as the beginning of their junior year and could still complete the MIS major without delaying their graduation date. Table 1 below briefly describes the courses in our new curriculum along with their outlines.

\section{CONCLUSIONS}

Significant curricular change is always difficult and time consuming, often for administrative or bureaucratic reasons. Our university, like many others, requires significant paperwork and processing lead time to make what may seem like simple changes in the curriculum. Changing the name of a course or its catalog description can take months and often requires sign-off by all other departments and colleges that may have an interest in the specific content area. While checks and balances have an important role in university governance they can make it difficult to support a curriculum that should be dynamic to reflect a rapidly evolving field.

External forces drive a need for periodic reevaluation of our curriculum. Two forces, changing industry needs [13] and the 2010 IS Undergraduate Program Guidelines emphasis on areas like strategy, information and project management, caused us to realize that our curriculum, last updated in 2006, was lagging behind current needs. Under normal circumstances embarking on another major curriculum revision after such a short lapse of time could have been difficult to justify or accomplish. However, the statewide "mandate" for conversion of all state universities to the semester system provided the opportunity to overhaul of the MIS curriculum now. Because of the massive number of classes and programs that have to be converted university wide before the fall of 2012, the university created a streamlined system to handle the load. And, while we are still in early stages of the process, we believe that the new system will facilitate approval on this much needed MIS curriculum overhaul. This paper therefore, presents the case of one MIS department undergoing curriculum change, with its driving factors, processes and resulting curriculum model in hopes it may help other IS departments facing similar circumstances.

\section{REFERENCES}

[1] Directive to the Board of Regents, Appendix A, Strategic Plan for Higher Education 20082017. http://uso.edu/strategicplan/downloads/docum ents/strategicPlan/USOStrategicPlan.pdf, accessed May 9, 2010 
[2] University System of Ohio, http://www.uso.edu/network/usoSchools/index .php, accessed May 9, 2010

[3] Strategic Plan for Higher Education 20082017.

http://uso.edu/strategicplan/downloads/docum ents/strategicPlan/USOStrategicPlan.pdf, accessed May 9, 2010

[4] ICIS 2009. Theme and Track List. http://ai.arizona.edu/icis2009/program/tracks.h $\underline{\mathrm{tml}}$, accessed May 11, 2010

[5] Benamati, J.H., Osdemir, Z.D., Smith, H.J. 2010. "Aligning Undergraduate IS Curricula With Industry Needs". Communications of the ACM, Vol. 53, 152-156.

[6] Bullen, C.V., Abraham, T., Gallagher, K., Simon, J.C., Zwieg, P. 2009. "IT Workforce Trends: Implications for Curriculum and Hiring". Communications of the Association for Information Systems, March 2010, Vol. 24, 129-140.

[7] Frost, R., Pike, J., Kenyo, L. 2008. "Generating Student Interest in the Information Systems Major: A strategic Framework for the Introductory Course". Issues in Information Systems Vol. IX, 188195. .

[8] Huang, W., Frost, R., McGann, S. 2006. "Integrating Business Acumen with IT Skills in the Same Course: A Case Study with Implications for Increasing IS Program Enrollments". Issues in Information Systems, Vol.VII, 62-66.
[9] Kesner, R.M. 2008. "Business School Undergraduate Information Management Competencies: A Study of Employer Expectations and Associated Curricular Recommendations". Communications of the Association for Information Systems, Vol. 23, 634-654.

[10] McGann, S., Frost, R., Matta, V. 2006. "Meeting Dynamic IS Market Demands: Leveraging Consulting Practices to Guide Curriculum Reform". Issues in Information Systems, Vol. VII, 210-215.

[11] McGann, S. 2007. Exploring the Evolution of IS Education: A Comprehensive Curriculum Review. Issues in Information Systems, Vol. VII, 154-159.

[12] McMurtrey, M.E., Downey, J.P., Zeltmann, S.M., Friedman, W.H. 2008. "Critical Skill Sets of Entry-Level IT Professionals: An Empirical Examination of Perceptions from Field Personnel". Journal of Information Technology Education, Vol. 7, 101-120.

[13] Topi, H., Valacich, J.S., Wright, R.T., Kaiser, K., Nunamaker, J.F.Jr., Sipior, J.C., Vreede, G.D., 2009. "IS 2010 Curriculum Guidelines for Undergraduate Degree Programs in Information Systems", Association for Computing Machinery (ACM), Association for Information Systems (AIS)

[14] Vanlengen, C.A. 2003. "CIS Curriculum PostDot-Com". Information Systems Education Journal, Vol. 1(3). 


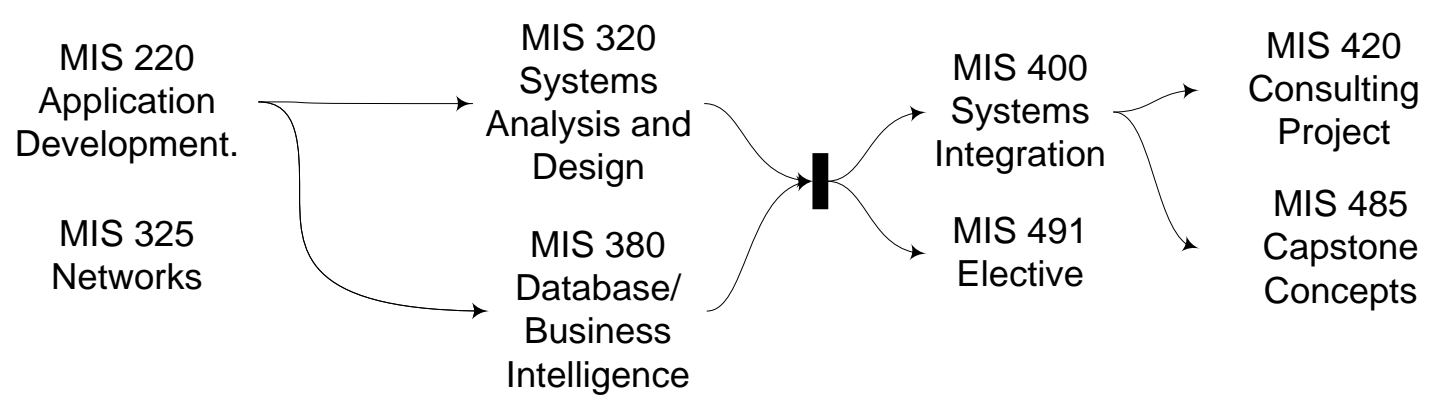

Figure 1: The current curriculum

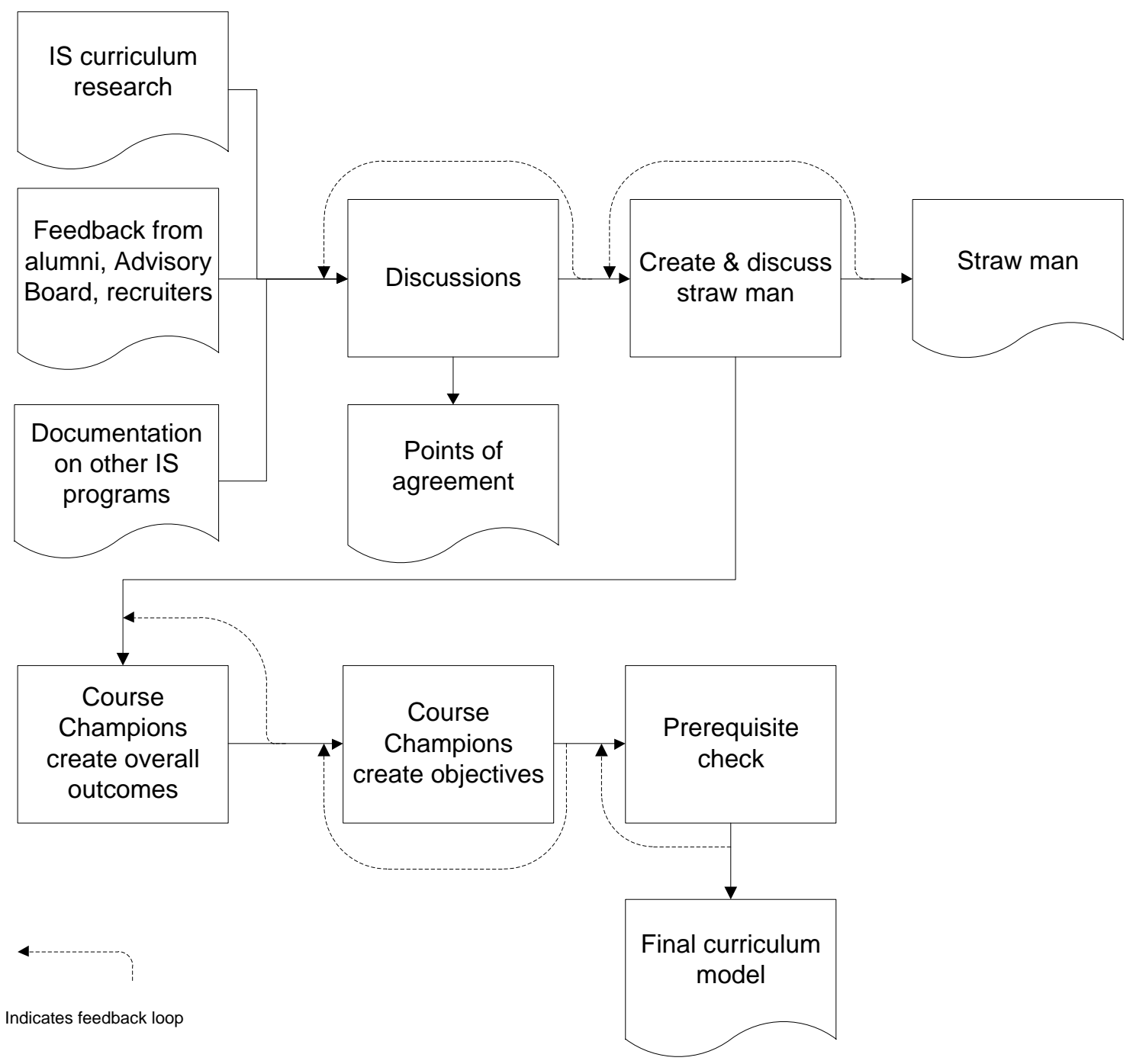

Figure 2: Curriculum Development Process 


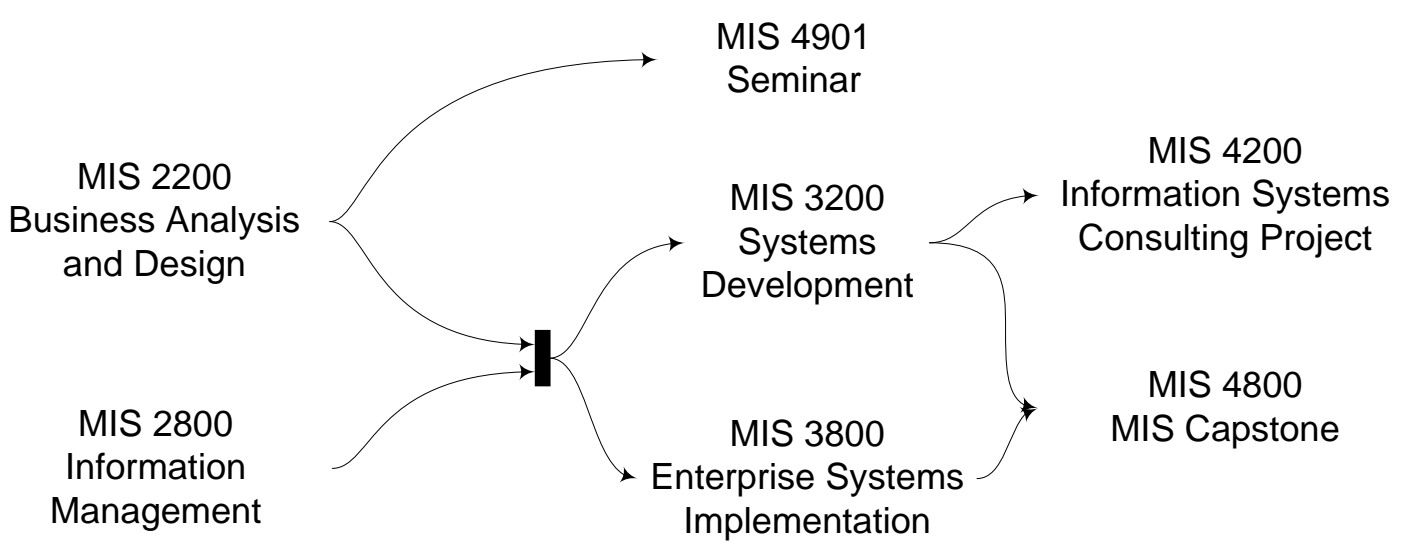

Figure 3: The new curriculum

\begin{tabular}{|c|c|}
\hline MIS 2200 Business Analysis and Design & $\begin{array}{l}\text { An introduction to Systems Analysis and Design. Topics include analyzing } \\
\text { the business case, requirements modeling, data and process modeling, and } \\
\text { development strategies, with an increased focus on object modeling and } \\
\text { project management. Students also learn about output and user interface } \\
\text { design, data design, systems architecture and implementation, and systems } \\
\text { operation, support and security. Students will analyze and design } \\
\text { information systems in a structured format using a contemporary systems } \\
\text { development methodology. }\end{array}$ \\
\hline MIS 2800 Information Management & $\begin{array}{l}\text { An introduction to database terminology, design, development, the } \\
\text { querying of databases, Business Intelligence and the management of } \\
\text { information in order to solve complex business problems. Topics include } \\
\text { the relational model, database normalization, basic and complex database } \\
\text { design, implementing a SQL database, basic and advanced SQL queries } \\
\text { and sub-queries, business intelligence concepts, data mart and data } \\
\text { warehouse technologies, data mining, the use of scorecards, dashboards and } \\
\text { reports, dimensions, key performance indicators (KPIs) and cubes. }\end{array}$ \\
\hline MIS 3200 System Development & $\begin{array}{l}\text { This course teaches the fundamentals of business application development } \\
\text { using a contemporary business programming language, framed in relevant } \\
\text { business contexts }\end{array}$ \\
\hline MIS 3800 Enterprise Systems Implementation & $\begin{array}{l}\text { This course teaches the fundamentals of business application development } \\
\text { using a contemporary business programming language, framed in relevant } \\
\text { business contexts }\end{array}$ \\
\hline MIS 4910 Seminar & $\begin{array}{l}\text { Special topics of current interest in the management information systems } \\
\text { area }\end{array}$ \\
\hline MIS 4200 Information Systems Consulting Project & $\begin{array}{l}\text { This course provides a refresher on system development techniques before } \\
\text { providing students with experience working on an information system } \\
\text { consulting/development project using live clients. }\end{array}$ \\
\hline MIS 4800 MIS Capstone & $\begin{array}{l}\text { This capstone seminar is designed to accomplish three primary goals: 1) } \\
\text { build deep business information system analysis and design skills in the } \\
\text { context of 'The Big Three' (Enterprise Systems, Business Intelligence } \\
\text { Systems and Collaboration Systems), 2) expand IS knowledge base and } \\
\text { understanding through intensive discussion and activities, 3) increase } \\
\text { career readiness and networking skills. }\end{array}$ \\
\hline
\end{tabular}

Table 1: Proposed Course List with Descriptions 